支部・集談会記事

\section{日本臨床外科学会秋田県支部抄録 （第34回秋田県支部例会）}

日程：平成31年 3 月 2 日（土） $14: 00$ 会場：本道40周年記念会館 $2 \mathrm{~F}$ 本道記念講堂

$\begin{array}{lll}\text { 代表世話人 山本 } & \text { 雄造 (秋田大学) } \\ \text { 代表世話人 } & \text { 南谷 } & \text { 佳弘 (秋田大学) } \\ \text { 代表世話人 山本 } & \text { 浩史 (秋田大学) } \\ \text { 当番世話人 南谷 } & \text { 佳弘 (秋田大学) }\end{array}$

\section{特別講演 1}

座長 中川拓（大曲厚生医療センター 呼吸 器外科)

「肺がん治療成績向上にむけて」

岩手医科大学 呼吸器外科 齊藤 元 先生

\section{特別講演 2}

座長 南谷 佳弘（秋田大学 胸部外科）

「免疫チェックポイント阻害薬時代の消化管腫瘍 学」

岩手医科大学 病理診断学講座

菅井 有 先生

1 脈管浸潤を伴う肝胆膵腫掦手術に打ける合併切除・血 行再建例の検討

秋田大学心臟血管外科

桐生健太郎，角浜孝行，山浦玄武，田中郁信，高木大地，荒井岳 史, 山本浩史

消化器外科領域において、脈管浸潤の有無は腫掦切除の根治性に おいて重要である。特に肝胆膵領域においては脈管の構築が複雑 であり、浸潤の程度によっては合併切除・再建を要する場合があ り、腫瘍の治瘾切除の可否や、予後へも影響を与える。

また、脈管温存する際にも腫瘍切除の際の血管損傷などによって 血行再建を要する場合がある。今回我々は、2017-2018年に扑け る当科で行なった消化器外科領域に扔ける血行再建症例について 検討したので報告する。

症例は 4 例で、内 2 例が腫瘍浸潤に伴う合併切除後の血行再建で あり、他の 2 例は術中損傷に伴う再建だった。合併切除症例は双 方膵癌であり、再建術式は、SMA-GDA直接吻合、SVGを用い たLGA-SMA Bypassであった。

当科では合併切除に伴う血行再建等の依頼があれば、積極的に行 う方針としており、科の枠を越えての術前検討と心臓血管外科手 技を生かした手術支援が成績向上に寄与できるのではないかと考 えている。カンファレンスを行い、互いに協力し、治療にあたる ことが重要であると考える。
2 出生時の呼吸不全で発症し右肺中下葉切除を施行した 先天性気管支狭窄症の 1 例

秋田大学小児外科

山形健基, 渡部 亮, 蛇口 环, 森井真也子, 吉野裕顕 症例は女児。41週 2 日、誘発分娩で出生、2,837g。Apgar $7 / 5$ 。 生直後から呼吸不全を認め、HFOによる人工呼吸器管理を開始。 はじめレントゲンで縦隔の左方偏位、右肺の過膨張と透過性低下 を認めたが、その後、透過性が充進し気腫状となった。CTで右 上葉気管気管支と右中間気管支幹狭窄、右中下葉の肺葉性気腫、 右上葉の無気肺を認めた。SIMVに移行できたが人工呼吸器から の離脱は困難で、次第に右中下葉の気腫が進行したため手術の方 針とした。右中間気管支幹狭窄が高度であることから、気管支形 成術は困難であると判断、右中下葉切除術を予定。日齢40に手術 を施行。腋下切開で開胸、下葉と中葉の過膨張と上中葉の分葉異 常を認めた。まず、右下葉切除を施行し、その後、右上葉に含気 が得られることを確認し右中葉を切除した。日齢102に退院。術 後 2 年現在まで呼吸器症状なく経過している。稀な先天性右中間 気管支幹狭窄の新生児例を経験したので、文献的考察を加え報告 する。

3 鼠径へルニア術前検查としての腹臥位 CT の有用性 市立秋田総合病院消化器外科

木村友昌, 佐藤 勤, 栗原由騎, 林 海斗, 新保知則, 若林俊樹, 菊地 功, 太田 栄, 伊藤誠司

【目的】当院では2016年から成人鼠径ヘルニアに対し腹垫鏡下腹 膜前䏶アプローチ法（TEP法）を導入した。TEP法のメリット のひとつとして、両側性の場合、片側性と同じ手術創から腹膜前 腔内の操作で対側のヘルニアが修復可能なことがある。そこで、 より正確な術前診断を目的に腹臥位 $\mathrm{CT}$ を施行したので、その成 績を報告する。【方法】対象は2017年 6 月から2018年11月までに ヘルニア手術前に腹卧位 $\mathrm{CT}$ を施行した成人68例であり、患者に 腹圧をかけてもらい単純 CTのみで行った。成績】 CT 検查のへ ルニア存在検出能は68例中 67 例、検出率 $98.5 \%$ であった。同様に ヘルニア分類診断能は68例中 65 例、診断率 $95.6 \%$ であった。この うち、身体所見で健側にヘルニアなしと診断され腹臥位 CTであ りと診断されたのは16例あった。【結語】腹臥位CTのヘルニア 検出率は高く、身体所見で診断されない健側のヘルニア検出に有 用であった。

4 当院における開腹虫垂切除と腹脘鏡下虫垂切除の比較 北秋田市民病院外科

煙山紘平, 宇佐美修悦, 川原田康, 栗原伸泰, 長岐雄志, 藤田 啓, 小林昭仁, 神谷 彰

【背景】当科では2014年11月より腹腔鏡下虫垂切除術を導入した。 腹腔鏡手術のメリットの一つとして傷が小さく、術後回復・退院 までの期間が短いことが挙げられている。一方で手術器具など開 腹手術に比べコストがかかると言われている。今回は当院の虫垂 切除に関して開腹手術と腹腔鏡下手術とを手術面とコスト面で比 較した。

【方法】当科における、2012年 4 月から 2018 年12月までの開腹虫 垂切除 $(n=35)$ と腹腔鏡下虫垂切除 $(n=42)$ とを(1)手術時間、 (2)出血量、(3)入院期間、(4)術後入院期間、(5)術後合併症、(6)利益 計算の 6 項目で比較した。(1)〜 (5)に関してはMann-Whitneyの U検定を使用した。

【結論】(1)手術時間は有意に腹腔鏡下手術の方が長いという結果 であったが、 $3 \sim 5$ 年目の若手が執刀することが多く、経験・技 
術の差が関与した可能性がある。(2)出血量は有意に腹腔鏡下手術 の方が少なかった。(3)入院期間、(4)術後入院期間、(5)術後合併症 （Grade 2 以上）に関しては有意差を認めなかった。(6)利益計算 では術式や手術器具の工夫により、克服された。さらに統計的・ 文献的考察を加えて報告する。

\section{5 食道癌 $\mathrm{ESD}$ 後に単独左胸膜播種を発症した 1 例} 由利組合総合病院外科 ${ }^{1}$, 秋田大学食道外科 ${ }^{2}$

米屋崇峻, 本山 悟 ${ }^{2}$, 佐藤雄亮 ${ }^{2}$

【症例】78歳、男性。【現病歴】2008年11月に胃癌に対して幽門側 胃切除術を施行しており、adenocarcinoma、pT 2 (SS)、ly 3 、 v 3、pN 2、pStage III A の病理診断で術後 SP 療法を行い、以降 1 年毎にCT と GIFでフォローをしていた。2017年10月の GIFで 上切歯列から $30 \mathrm{~cm}$ の食道粘膜に $0-$ II b 病変を認め、生検で高分 化扁平上皮癌が検出され、11月に ESDを施行した。組織診でpT $1 \mathrm{a}-\mathrm{MM} 、 \mathrm{pHM} 1 、 \mathrm{pVM} 0 、 \mathrm{INFb} 、 \mathrm{ly}(-) 、 \mathrm{v}(+)$ の病理診断 だったため追加治療としてCRTを行う方針とした。12月から 2018年 1 月までCRT (FP 2 コース+60Gy) を行い、その後の CTやGIFでは再発所見は認めなかった。CRT施行して 9 ヶ月後 の10月に、1 1 个月前からの呼吸苦、胸痛、倦意感を主訴に受診。 胸部レントゲンで左肺野全体的に胸水貯留を認めた。胸垫ドレー ンを挿入し、淡血性の胸水が引けた。血清SCC は陰性だったが、 胸水細胞診ではSCCが検出された。GIF、CTでは局所再発、リ ンパ節再発、遠隔転移は認めず、単独の左胸膜播種再発と診断し た。化学療法の希望はなく、胸水貯留が改善してきたところで胸 膜癒着療法を計 4 回施行し退院となった。【考察】医中誌および PubMedでも同様の症例の報告は検索できなかった。原因として はESDの粘膜下層への局注時に癌細胞を胸膜直下まで広げてし まったことが可能性として考えられるが検証するのは難しい。【結 語】食道癌 $\mathrm{ESD}$ 後に局所再発やリンパ節再発を認めずに単独の 胸膜播種を発症した稀な症例を経験した。

6 術後 1 ケ月で早期再発し Pembrolizumabが著効した 肉腫様肺癌の小腸転移

秋田大学胸部外科 ${ }^{1}$, 秋田大学消化器外科 ${ }^{2}$

中麻衣子 ${ }^{1}$, 今井一博 ${ }^{1}$, 栗原伸泰 ${ }^{1}$, 松尾 翼 1 , 渡邊伸之助 ${ }^{1}$, 岩 井英頃 ${ }^{1}$, 南谷佳弘 ${ }^{1}$, 渡邊 翼 ${ }^{2}$, 阿部ゆき ${ }^{2}$, 山本雄造 ${ }^{2}$ 60 代男性。検診にて胸部異常陰影を指摘されCTにて右上葉肺癌 疑い。気管支鏡検査にて腺癌の診断で手術の方針。右肺上葉切除 術および縦隔リンパ節郭清を施行し、第 7 病日に退院。最終病理 診断では肺腺癌 pStage I Bであった。

術後 1 ケ月に歩行時の呼吸苦を主訴に外来受診。胸部XPにて多 量の胸水を認め、CTにて多発する胸膜播種を認めた。手術標本 の再検討を行った結果、肺腺癌の一部に肉腫様癌の成分が含まれ ていることが判明し、肉腫様肺癌再発との診断を得た。

肉腫様肺癌再発に対する治療として CBDCA+PTXを計 5 コース 施行したところでPDの判定。胸膜播種病変からの検体にて、 PD-L 1 が高発現であったことから Pembrolizumabを導入。直後 に間質性肺炎疑いのため、PSL 導入し $5 \mathrm{mg} / \mathrm{day} に て$ 維持し経過 観察としていた。フォローのCTにて腫瘍が一部増大となったと ころでPembrolizumabを再開とし、CRに近いPRを維持していた。 治療再開し計11コースを行っているあたりから、右側腹部痛を自 覚。CTにて腸重積を認め、消化器内科紹介。下部消化管内視鏡 検查にて小腸腫瘍の診断。生検では悪性所見得られず、内䏶を占 拠する病変であり、消化器外科にて手術施行し、最終病理結果に て肉腫様肺癌の小腸転移であった。
7 Pembrolizumab の著効を認めた肉腫様肺癌の 1 例 大曲厚生医療センター呼吸器外科

森 奏美, 中川 拓, 高嶋祉之具, 鈴木陽香

【はじめに】肉腫様肺癌は化学療法抵抗性かつ急速進行性の予後 不良な疾患である。今回、我々は肉腫様肺癌と診断され、Pembrolizumabが著効した症例を経験したので報告する。【症例】 72 歳男性。右上葉〜中葉の連続性病変が 1 ケ月で急速に増大したた め当科紹介。気管支鏡検查で診断に至らず、胸腔鏡下右肺生検術 を施行。迅速診断で胸膜播種を認める T 4 N 2 M 1 a、stage 4 A の肺腺癌とされるも、最終病理診断で肉腫様肺癌と診断。EGFR (-)、ALK (-)、TPS $(22 \mathrm{C} 3)=60 \%$ の結果から、初回治療とし てPembrolizumabを開始。8コース終了後の評価CTで腫瘍はほ ほ消失し完全奏効 $(\mathrm{CR})$ 。16コース終了時点で、薬剤性腎障害 (Grade 2 ) を発症したためPembrolizumabを休薬としたが、2 ケ月経過後も CRを維持している。後に、 KRAS G12V (+) であ ることが判明した。【考察】予後不良とされている肉腫様肺癌に Pembrolizumabなどの免疫療法が効く可能性が示唆された。

8 術前化学療法により根治手術が可能となった膿瘍形 成, 肝転移を伴う進行大腸癌の 1 例

平鹿総合病院外科

茂木はるか, 榎本好恭, 久保田洋介, 洞口正志, 川原田康, 宮㟝 勇希，滝戸成人，石井大介，武富龍一

症例は 80 代女性。右季肋部痛を主訴に受診し、採血で炎症反応高 值を認めた。CTで横行結腸癌穿孔に伴う膿瘍と肝転移が疑われ、 症状改善目的に回腸人工肛門造設術、膿瘍ドレナージを施行した。 下部消化管内視鏡で、横行結腸に腫瘍を認め、腺癌（RAS変異 陽性）の診断となった。mFOLFOX 6 +Bevacizumab 療法を開始 し、 5 コース終了後のCTでPR、切除可能と判断し、初診から 約 6 ケ月後に右半結腸切除術、肝S 6 部分切除術、胆囊摘出術、 腹壁合併切除術、人工肛門閉鎖術を施行した。病理組織学検查で はypT 4 b (SI : 腹直筋)、ypN 1 a、ypM 1 a、ypStage IV a であり、 組織学的治療効果判定はgrade $1 \mathrm{~b}$ であった。術後補助化学療法 としてTS- $180 \mathrm{mg} /$ 日を 1 年間継続した。術後 2 年経過し無再 発生存中である。膿瘍および浸潤臓器を含めた広範囲な切除は手 術侵襲が大きく、また癌遺残による局所再発の可能性が高い。術 前化学療法に関して十分なエビデンスはないが、浸潤臟器の温存 や手術侵襲の軽減という点から有用な選択肢と考えられた。

\section{9} の成績

秋田大学消化器外科

渡邊 翼, 打波 宇, 吉岡政人, 飯田正毅, 渡辺 剛, 中川康彦, 阿部ゆき, 八木史生, 横山直弘, 熊谷健太, 大塚直彦, 山本雄造 肝転移を有する大腸癌では、予後や安全性の観点から、原発巣と 同時に肝切除すべきか、待機して切除すべきか一定の見解はない。 今回、当科に扔ける大腸癌同時性肝転移症例の成績を振り返り、 大腸癌と肝転移同時切除の妥当性を検証した。2004年 1 月から 2017年12月までに当科で外科的治療を受けた大腸癌同時性肝転移 64例の術後合併症と予後を検討。43例は原発巣と同時に肝切除を 施行され、21例は原発巣切除後に待機的な肝切除が施行されてい た。同時切除の短期成績は、縫合不全 3 例 (7.3\%、全て直腸癌)、 胆汁漏 2 例 $(4.9 \%)$ 、手術関連死 0 例と、比較的良好な成績であ った。原発巣切除後の 5 年生存率は同時群で $58.4 \%$ 、待機群では $38.1 \%$ と有意差は認めなかった $(\mathrm{p}=0.29)$ が、待機群で悪い傾向 にあった。ただし、肝転移Grade は待機群で有意にCを多く認め 
た $(22 \%$ vs. $47.8 \%, \mathrm{p}-0.03)$ 。大腸癌と肝転移の同時切除は安全 に施行可能である。予後からみても切除可能症例を待機する理由 はないと思われた。

10 放射線化学療法後 conversion surgery を施行した局所 進行膵癌の 1 例

平鹿総合病院外科 ${ }^{1}$, 平鹿総合病院病理診断科 ${ }^{2}$

林健次郎 ${ }^{1}$, 宮㠃勇希 ${ }^{1}$, 茂木はる 1 $^{1}$, 石井大介 ${ }^{1}$, 武富龍一 ${ }^{1}$, 滝 戸成人 ${ }^{1}$, 川原田康 ${ }^{1}$, 久保田洋介 ${ }^{1}$, 洞口正志 ${ }^{1}$, 榎本好恭 ${ }^{1}$, 齊藤 研 $^{1}$, 齊藤昌宏 ${ }^{2}$

症例は59歳男性、背部痛を主訴に来院。CTにて膵鈎部に膵癌を 疑う腫瘤性病変を認め、CA19-9、DUPAN-2 の上昇も認めた ため、臨床的に膵鉤部癌と診断した。しかし、腫瘍はSMA と広 範に接触しており、切除不能局所進行膵癌と判断し放射線化学療 法を施行する方針とした。RT (54Gy/30fr) + GEM併用 2 コー スと GEM+nab-PTX (GN) 療法8コースを行ったところ腫瘍マ 一カーは正常範囲となり、CTにて病変の縮小を認めSMAから は剥離可能と判断し、亜全胃温存膵頭十二指腸切除術、SMA 神 経叢全周郭清を施行した。病理組織所見にて、膵銁部の病変部位 には異型細胞を認めず、痝痕組織のみで組織学的効果判定は Grade 3 と判断した。近年、非手術療法が奏功した切除不能膵癌 に対して、 conversion surgeryを行うことで長期生存が得られた 症例が報告されている。GN療法は腫瘍縮小効果が高く、ダウン ステージングによる切除対象の増加や根治切除率の増加による予 後向上が期待されている。 